\title{
OPEN Groundwater in sedimentary basins as potential lithium resource: a global prospective study
}

\author{
Elza J. M. Dugamin ${ }^{1 凶}$, Antonin Richard ${ }^{1}$, Michel Cathelineau ${ }^{1}$, Marie-Christine Boiron ${ }^{1}$, \\ Frank Despinois ${ }^{2} \&$ Anne Brisset $^{2}$
}

Electric cars will require to increase the production of lithium dramatically (up to 2 Mtons lithium equivalent carbonate per year by 2030). However, conventional hard-rock and salar mining are facing environmental and social concerns. Therefore, alternative lithium resources may help meeting the global demand for the next decades. Here, we provide a systematic analysis of published lithium concentration in about 3000 samples of groundwater from 48 sedimentary basins worldwide. The highest lithium concentrations $\left(>10^{2} \mathrm{mg} \mathrm{l}^{-1}\right.$ ) are primarily found in high salinity waters (Total Dissolved Solids $>10^{5} \mathrm{mg} \mathrm{l}^{-1}$ ) and are in the same range as brines from the most productive salars. Conservative estimations based on fluid volume and lithium concentration in selected reservoirs indicate that these lithium resources are comparable to salars and hard-rock mines (0.1-10 Mtons lithium). Therefore, lithium in groundwater from sedimentary basins could be a significant potential resource for the next decades.

Lithium is widely used for energy storage (Li-ion rechargeable batteries, around 70\% global lithium consumption) in ceramics, glass and lubricating grease ${ }^{1}$. The lithium demand had increased from 37 ktons of lithium in 2016 to 52 ktons of lithium in 2018. It is forecasted to exceed 0.38 Mtons of lithium by 2028 due to the increased need for rechargeable Li-ion batteries for electromobility ${ }^{2}$. Currently exploited primary lithium resources are found in hard rocks (granites, aplites and pegmatites) and closed basin brines (salars) (respectively about 26 and $58 \%)^{3}$. The total global resource is estimated to be 86 Mtons of lithium ${ }^{1}$. Although the current resources are far higher than the expected demand for the next ten years, momentary tensions may arise, linked to local difficulties in the mining operations. In particular, increasing environmental concerns and challenges in the social acceptance of salar exploitations (e.g. water use in desertic areas) may seriously affect future production ${ }^{4}$. In addition, energy costs and $\mathrm{CO}_{2}$ balance for mining and transportation of hard rocks may influence the sustainability of this type of operation ${ }^{5}$. Therefore, developing alternative lithium resources may significantly contribute to meeting the global demand.

Groundwaters in sedimentary basins have been widely recognized for carrying appreciable amounts of metals (hundreds to thousands of $\mathrm{mg} \mathrm{l}^{-1}$ ) in their dissolved load ${ }^{6}$. The potential "ore-forming solutions"7 may also be considered "liquid ores" 8 . In the perspective of increasing lithium demand, groundwaters from high-enthalpy geothermal fields have recently attracted considerable attention for extracting lithium as a by-product of geothermal energy $^{9}$ (e.g. Salton Trough ${ }^{10}$ ). Deep saline groundwaters in sedimentary basins could also be of interest but have not been studied in detail. Yet, sedimentary formation waters are usually produced in large volumes in oil and gas fields, low-enthalpy geothermal fields and CCUS (carbon capture, utilisation and storage) operations in saline reservoirs ${ }^{11-13}$. Lithium concentrations in these waters have been widely documented. However, a global analysis of the potential resource in lithium is still lacking. Here, a database of published lithium concentrations from sedimentary formation waters worldwide was built. The main features of the reservoirs (depth, temperature and age of host rocks) and chemical parameters, such as Total Dissolved Solids were examined to evaluate the first-order parameters controlling lithium concentrations in sedimentary formation waters as well as $\mathrm{Mg} / \mathrm{Li}$ which is relevant for lithium recovery ${ }^{14,15}$. The lithium resource was calculated for selected lithium-rich reservoirs based on available lithium concentrations and conservative estimates of fluid volumes. The estimated lithium resources were compared to current lithium resources from hard rocks and salars to examine how they can face forecasted lithium demand.

Data compilation and processing. The database built for this work covers 48 sedimentary onshore and offshore basins worldwide, mainly from North America and Europe (Fig. 1, Table 1). Some of the selected basins

${ }^{1}$ GeoRessources, Université de Lorraine, CNRS, CREGU, Nancy, France. ${ }^{2}$ TotalEnergies, Centre Scientifique et Technique Jean Féger, Pau, France. ${ }^{\square}$ email: elza.dugamin@univ-lorraine.fr 


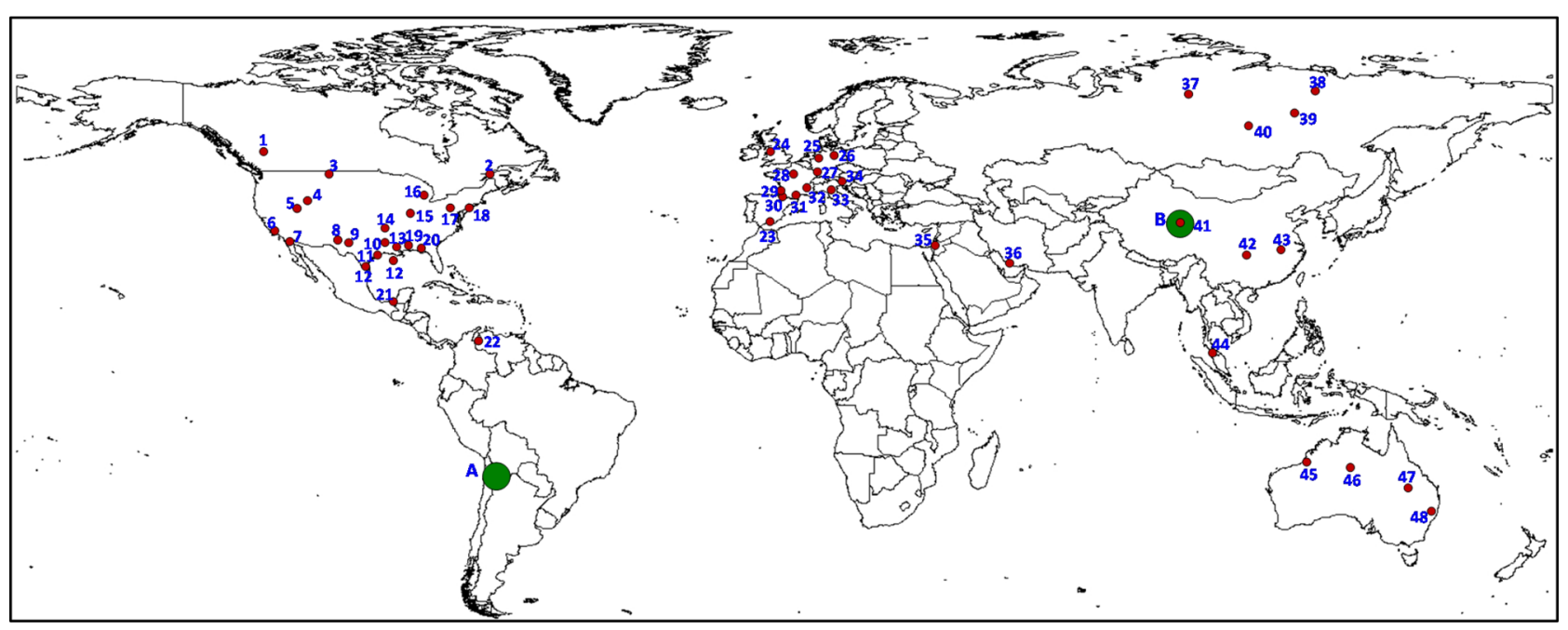

Figure 1. World map showing the sedimentary basins, salars and salt lakes with published data used in this study. Red dots: sedimentary formation waters; green circles: closed basin brines (salars and salt lakes). The numbers and capital letters in blue refer to the identification number in Table 1.

are subjected to oil-gas-coal-shale-gas extraction, and exploitation for geothermal energy and $\mathrm{CO}_{2}$ storage in some others. Analyses of about 3000 individual samples of sedimentary formation waters were considered from published sources, the number of data ranging between 2 to 330 per basin (Table 1). All selected data correspond to reservoir waters (i.e. "formation waters") and spring waters. According to international stratigraphic charts, the age of the reservoir host rocks spans from Proterozoic to Cenozoic ${ }^{16}$.

The depth of water sampling (in metres) along the drill holes is reported as a function of the ground surface or the seafloor (for onshore and offshore basins, respectively). When available from the published sources, the sample temperature $\left(\right.$ in $^{\circ} \mathrm{C}$ ) is measured in the drill holes by wireline thermometers or, by default, estimated from the local geothermal gradient or chemical geothermometers. Besides lithium concentrations, the database also includes $\mathrm{Mg} / \mathrm{Li}$ mass ratio. The salinity expressed as total dissolved solids (TDS) based on the sum of concentrations of major ions $\left(\mathrm{Na}^{+}, \mathrm{K}^{+}, \mathrm{Ca}^{2+}, \mathrm{Mg}^{2+}, \mathrm{Cl}^{-}, \mathrm{SO}_{4}{ }^{2-}, \mathrm{NO}_{3}{ }^{-}, \mathrm{F}^{-}, \mathrm{HCO}_{3}{ }^{-}, \mathrm{CO}_{3}{ }^{2-}\right)$, was calculated from the published source data and expressed in $\mathrm{mg} \mathrm{l}^{-1}$. Lithium and magnesium concentrations from about 500 published water analyses from about 44 closed basins (salars and salt lakes) from South America and China were also compiled. They are hereafter referred to as "closed basin" fluids. A posteriori quality control analysis could not be reasonably carried out on the published data used in this database.

The reservoirs on which the lithium resources were estimated combine: (1) relatively elevated median lithium concentration $\left(>10 \mathrm{mg} \mathrm{l}^{-1}\right)$, (2) a relatively homogeneous lithium concentration (i.e. lower and upper quartiles in the same order of magnitude), (3) number of samples per reservoir above five and (4) known geographic location and depth of samples. The values of all parameters are available from the published sources (Table 2). A resource is "a concentration of naturally occurring solid, liquid, or gaseous material in or on the Earth's crust in such form and amount that economic extraction of a commodity from the concentration is currently or potentially feasi-

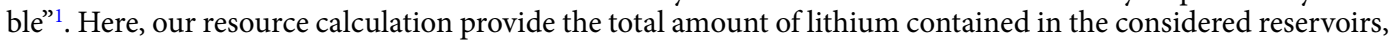
without considering the storage coefficient and lithium recovery rates. The lithium resources $\left(\mathrm{R}_{\mathrm{Li}}\right.$ in Mtons) of the selected reservoirs were estimated using two main parameters: (1) the volume of water in the reservoir, estimated by considering the surface area $\left(\mathrm{A}\right.$ in $\left.\mathrm{km}^{2}\right)$, the thickness $(\mathrm{T}$ in $\mathrm{m})$ and the porosity (P, expressed between 0 and 1 where 1 corresponds to a porosity of $100 \%$ ) of the reservoirs, and (2) the water density ( $D$, either provided in the published sources or conservatively set at $1 \mathrm{~g} . \mathrm{cm}^{-3}$ by default) and the lithium concentration (C in $\left.\mathrm{mg} \mathrm{l}^{-1}\right)$. The following equation was used ${ }^{17}$ :

$$
\mathrm{R}_{\mathrm{Li}}=\mathrm{A} \times \mathrm{T} \times \mathrm{P} \times \mathrm{D} \times \mathrm{C}
$$

The surface area is the most sensitive parameter in Eq. (1). Therefore, given that storage coefficient and lithium recovery rate were not taken into account, minimizing the volume of the lithium-rich reservoirs is crucial to provide reasonably conservative resource estimates. The total surface area of the considered reservoir was not taken into account. A circle with a radius of $2 \mathrm{~km}$ around each sample site (i.e. drill hole) was supposed to define the area related to a single drill hole. When drill holes are less than $4 \mathrm{~km}$ to each other so that circles overlap, the surface area associated with the group of drill holes was deemed equivalent to that of the smallest circle enclosing the considered group of drill holes. Then, the total surface area (A in Eq. (1)) for a given reservoir was estimated according to the sum of the surface areas considered for the different drill holes and groups of drill holes. The conservative value for reservoir thickness was estimated based on the difference between the shallowest and deepest samples. The representative lithium concentration are supposed to range between the lower and upper quartiles $\left(\mathrm{Q}_{1}\right.$ and $\mathrm{Q}_{3}$ respectively) of the available data for each reservoir. The porosity values are seldom reported in the published sources. The porosity generally tends to decrease with increasing depth. However, this trend is accompanied by a wide dispersion of porosity values due to changes in lithology and cementation 


\begin{tabular}{|c|c|c|c|c|}
\hline Countries & Basin name & $\begin{array}{l}\text { Identification } \\
\text { number }\end{array}$ & Number of samples & References \\
\hline \multicolumn{5}{|c|}{ Closed basin brines } \\
\hline Argentina & Puna-Atacama-Altiplano-Northwest & A & 490 & $\begin{array}{l}\text { Ericksen et al. 1976; Ericksen and Salas 1987; Risacher and Fritz } \\
\text { 1991; Risacher et al. 1999; Steinmetz et al. 2018; Gabriela et al. } \\
2020\end{array}$ \\
\hline China & Qaidam & B & 13 & Qishun et al. 2010; Tan et al. 2011 \\
\hline \multicolumn{5}{|c|}{ Sedimentary formation waters } \\
\hline Australia & Amadeus & 46 & 26 & Andrew et al. 2005 \\
\hline Australia & Canning & 45 & 19 & Ferguson et al. 2007 \\
\hline Australia & Eromanga & 47 & 10 & von Strandmann et al. 2014 \\
\hline Australia & Murray & 48 & 42 & Cartwright et al. 2004 \\
\hline Canada & Quebec & 2 & 5 & Pinti et al. 2011 \\
\hline Canada & West Canadian-Alberta & 1 & 147 & $\begin{array}{l}\text { Connolly et al. 1990; Hitchon 1971; Eccles and Berhane 2011; } \\
\text { Hitchon } 2001\end{array}$ \\
\hline China & Jianghan & 43 & 12 & Yu et al. 2021 \\
\hline China & Qaidam & 41 & 27 & Qishun et al. 2010; Tan et al. 2011 \\
\hline China & Sichuan & 42 & 92 & Xun et al. 1997; Xun et al. 2018; Gao et al. 2020 \\
\hline England & Cheshire-Worcester & 24 & 15 & Tellam 1995 \\
\hline France & Aquitaine & 29 & 81 & Négrel et al. 2012 \\
\hline France & Gulf of Lion & 31 & 6 & Aquilina et al. 2002 \\
\hline France & Limagne & 32 & 10 & Millot and Négrel 2007 \\
\hline France & Paris & 28 & 79 & $\begin{array}{l}\text { Michard and Bastide 1988; Fontes and Matray 1993; Millot and } \\
\text { Négrel } 2007 \text { Linard et al. 2011; Millot et al. 2011; Castillo et al. } \\
2015\end{array}$ \\
\hline France & Pyrenean Foothills & 30 & 3 & Millot and Négrel 2007 \\
\hline France-Germany & Rhine Graben & 27 & 65 & $\begin{array}{l}\text { Pauwels et al. 1993; Aquilina et al. 1997; Millot and Négrel 2007; } \\
\text { Sanjuan et al. 2010; Stober and Butcher 2015; Sanjuan et al. 2016; } \\
\text { Sanjuan et al. 2020 }\end{array}$ \\
\hline Germany & Northwest German & 26 & 45 & Kloppmann et al. 2001; Luders et al. 2010 \\
\hline Germany & Southern North Sea-Anglo Dutch & 25 & 12 & Grobe and Machel 2002 \\
\hline Hungary & Pannonian & 34 & 129 & $\begin{array}{l}\text { Varsanyi et al. 1997; Varsanyi and Kovacs 2009; Rowland et al. } \\
2011\end{array}$ \\
\hline Iran & Zagros Foldbelt & 36 & 98 & Mirnejad et al. 2011; Bagheri et al. 2014; Boschetti et al. 2020 \\
\hline Israel & Sinai-Levant & 35 & 22 & Chan et al. 2002 \\
\hline Italy & Po & 33 & 36 & Boschetti et al. 2011 \\
\hline Mexico & Salinas-Sureste & 21 & 32 & Birkle et al. 2002; Birkle et al. 2009 \\
\hline Russia & Anabar-Olenek & 39 & 9 & Alexeev et al. 2020 \\
\hline Russia & Nepa-Botuoba & 38 & 7 & Alexeev et al. 2020 \\
\hline Russia & Tunguska & 37 & 8 & Alexeev et al. 2020 \\
\hline Russia & Vilvuy & 40 & 6 & Alexeev et al. 2020 \\
\hline Spain & Betic Cordillera & 23 & 75 & Sanchez et al. 1999 \\
\hline Thailand & Pattani & 44 & 20 & Lundegard and Trevena 1990 \\
\hline USA & Appalachian & 17 & 184 & Sanders 1991; Dresel and Rose 2010; Skeen 2010 \\
\hline USA & Black Warrior & 19 & 2 & Collins 1976 \\
\hline USA & Delaware & 9 & 70 & Bodine and Jones 1990 \\
\hline USA & East Texas Salt & 11 & 5 & Collins 1976 \\
\hline USA & Forest City & 14 & 23 & Banner et al. 1989 \\
\hline USA & Georges Bank & 18 & 14 & Hogan and Blum 2003 \\
\hline USA & Green River & 4 & 5 & Collins 1976 \\
\hline USA & Gulf Coast Tertiary & 12 & 330 & $\begin{array}{l}\text { Collins 1976; Macpherson 1989; Land and Macpherson 1992; } \\
\text { Land 1995 }\end{array}$ \\
\hline USA & Illinois & 15 & 144 & $\begin{array}{l}\text { Stueber and Walter 1991; Stueber et al. 1993; Demir and Seyler } \\
1999\end{array}$ \\
\hline USA & Michigan & 16 & 112 & Wilson and Long 1993 \\
\hline USA & Midland-Permian & 8 & 57 & Stueber et al. 1998 \\
\hline USA & Mississippi Salt & 13 & 62 & Carpenter et al. 1974; Collins 1976 \\
\hline USA & North Louisiana Salt & 10 & 105 & Moldovanyi and Walter 1992 \\
\hline USA & Northeast Gulf Salt & 20 & 2 & Collins 1976 \\
\hline USA & Salton Trough & 7 & 15 & Thompson and Fournier 1988; Williams and McKidden 1989 \\
\hline USA & San Joaquin & 6 & 66 & Merino et al. 1975; Fisher and Boles 1990 \\
\hline Continued & & & & \\
\hline
\end{tabular}




\begin{tabular}{|l|l|l|l|l|}
\hline Countries & Basin name & $\begin{array}{l}\text { Identification } \\
\text { number }\end{array}$ & Number of samples & References \\
\hline USA & Williston & 3 & 38 & Collins 1976; Peterman et al. 2016 \\
\hline USA & Wind River & 5 & 5 & Collins 1976 \\
\hline Venezuela & Maracaibo & 22 & 10 & Boschetti et al. 2016 \\
\hline
\end{tabular}

Table 1. Published sources used for building the database. The identification number refers to Fig. 1. References are listed in the Supplementary references section.

\begin{tabular}{|c|c|c|c|c|c|c|c|c|c|}
\hline \multirow[b]{2}{*}{ Basin } & \multirow[b]{2}{*}{ Reservoir } & \multirow[b]{2}{*}{ Age of host rocks } & \multirow{2}{*}{\begin{tabular}{|l} 
Porosity \\
min-max
\end{tabular}} & \multirow[b]{2}{*}{ Density $\left(\mathrm{g} \mathrm{cm}^{-3}\right)$} & \multirow{2}{*}{$\begin{array}{l}\begin{array}{l}\text { Lithium } \\
\text { concentration } \\
\left(\mathrm{mg} \mathrm{l}^{-1}\right)\end{array} \\
\mathrm{Q}_{1}-\mathrm{Q}_{3}\end{array}$} & \multirow[b]{2}{*}{ Thickness (m) } & \multirow[b]{2}{*}{$\begin{array}{l}\text { Surface area } \\
\left(\mathbf{k m}^{2}\right)\end{array}$} & \multirow{2}{*}{$\begin{array}{l}\begin{array}{l}\text { Resource } \\
\text { (Mtons) }\end{array} \\
\begin{array}{l}\text { Scenario 1- } \\
\text { Scenario } 2\end{array}\end{array}$} & \multirow[b]{2}{*}{ Reference } \\
\hline & & & & & & & & & \\
\hline \multirow{2}{*}{ Appalachian } & Oriskany & Devonian & \multirow{7}{*}{$0.05-0.15$} & 1 & $148-277$ & 2101.5 & 92.7 & $1.44-8.09$ & 44 \\
\hline & Medina & Silurian & & 1.14 & $44-75$ & 132 & 40.3 & $0.01-0.07$ & 45 \\
\hline Salton Trough & $\begin{array}{l}\text { Salton Sea Geo- } \\
\text { thermal System }\end{array}$ & Quaternary & & 1.12 & $48-206$ & 140 & 37.4 & $0.01-0.18$ & 46 \\
\hline $\begin{array}{l}\text { North Louisiana } \\
\text { Salt }\end{array}$ & Atlanta & Jurassic & & 1.2 & $194-236$ & 90 & 20.6 & $0.02-0.08$ & 47 \\
\hline \multirow{2}{*}{$\begin{array}{l}\text { West Canadian- } \\
\text { Alberta }\end{array}$} & Basal Quartz & Cretaceous & & 1.1 & $11-15$ & 640 & 40 & $0.02-0.06$ & \multirow{2}{*}{48} \\
\hline & \begin{tabular}{|l|} 
Leduc \\
\end{tabular} & Devonian & & 1.1 & $20-34$ & 651 & 75.4 & $0.05-0.28$ & \\
\hline Rhine Graben & Landau & Paleocene & & 1.04 & $15-24$ & 674 & 13 & $0.01-0.03$ & 49 \\
\hline
\end{tabular}

Table 2. Lithium resource estimates for the considered reservoirs. $\mathrm{Q}_{1}$ and $\mathrm{Q}_{3}$ : quartiles 1 and 3 respectively.

rate. According to reference databases of reservoir porosity in sedimentary basins, the median porosity of the siliciclastic and carbonate reservoirs evolves approximatively from 24 to $10 \%$ and 18 to $6 \%$ respectively with increasing depth ${ }^{18}$. Here, the range of possible porosity values considered for each reservoir is between 5 and $15 \%$ (Table 2). Simultaneously to our estimation of the lithium resources, published estimates of lithium resources in known and exploited hard-rocks, salars and sedimentary formation waters were compiled ${ }^{14,17,19-29}$ (Table 3).

\section{Lithium geochemistry in sedimentary formation waters}

The database covers a wide range of TDS values from freshwaters $\left(<10^{3} \mathrm{mg} \mathrm{l}^{-1}\right)$, to brackish waters $\left(10^{3}-10^{4} \mathrm{mg} \mathrm{l}^{-1}\right)$, saline waters $\left(10^{4}-10^{5} \mathrm{mg} \mathrm{l}^{-1}\right)$ and brines $\left(>10^{5} \mathrm{mg} \mathrm{l}^{-1}\right)^{30}$. The ranges of lithium concentrations in sedimentary formation waters and closed basin fluids are from $1.2 \times 10^{-4}$ to $1800 \mathrm{mg} \mathrm{l}^{-1}$ and $2 \times 10^{-3}$ to $4720 \mathrm{mg} \mathrm{l}^{-1}$, respectively (Fig. 2). Closed basin fluids show lithium concentrations mostly between 3.8 and $488 \mathrm{mg} \mathrm{l}^{-1}\left(\mathrm{Q}_{1}\right.$ and $\mathrm{Q}_{3}$, respectively) while those from sedimentary formation waters classified as "brines" (i.e. TDS $\left.>10^{5} \mathrm{mg} \mathrm{l}^{-1}\right)$ are mostly between 0.5 and $37 \mathrm{mg} \mathrm{l}^{-1}\left(\mathrm{Q}_{1}\right.$ and $\mathrm{Q}_{3}$, respectively). Lithium concentrations show a positive correlation with TDS values (Fig. 2a). However, an extensive range of $2-3$ orders of magnitude in lithium concentrations is observed in sedimentary formation waters for a given TDS value. The lithium concentrations in the closed basin fluids overlie the highest lithium concentrations in the sedimentary formation waters for a given TDS value. Some sedimentary formation waters have, therefore, similar lithium concentrations to those found in currently exploited salars.

In sedimentary formation waters, high lithium concentrations $\left(>10^{2} \mathrm{mg} \mathrm{l}^{-1}\right)$ may be encountered from about 400 to $6000 \mathrm{~m}$ and 20 to $300{ }^{\circ} \mathrm{C}$ but there is no overall correlation (Fig. 2b,c). However, the lowest values of the lithium-temperature pairs (Fig. 2b) define a pseudo-trend of increasing lithium with temperature.

Most of the $\mathrm{Mg} / \mathrm{Li}$ ratio in sedimentary formation waters are between 14 and 218 compared to 12 to 34 in closed basin fluids $\left(\mathrm{Q}_{1}\right.$ and $\mathrm{Q}_{3}$, respectively). Lithium concentration shows a rough negative correlation with $\mathrm{Mg} / \mathrm{Li}$ ratios, although the data are widely scattered (Fig. 2d). In closed basin brines, lithium extraction is more favourable when $\mathrm{Mg} / \mathrm{Li}$ ratio is lower than 10 as the magnesium prevents the formation of lithium chloride, which is the first step towards forming the desired end product lithium carbonate ${ }^{14,15}$. For example, brines from the salar of Uyuni show an $\mathrm{Mg} / \mathrm{Li}$ ratio of 19 , much higher than those in the salars of Atacama (6.4) and del Hombre Muerto (1.4) $)^{19,22}$. For high-Mg brines such as those from salt lakes where $\mathrm{Mg} / \mathrm{Li}$ exceeds 70 , new technologies have been developed such as solvent extraction, adsorption and nanofiltration ${ }^{15}$.

Median values for lithium concentration per basin range from $3 \cdot 10^{-3}$ to $224 \mathrm{mg} \mathrm{l}^{-1}$ (Fig. 3). At the scale of a single basin, the distribution of lithium concentration may be rather homogeneous (i.e. lower and upper quartiles in the same order of magnitude) or highly scattered (i.e. over two orders of magnitude difference between the lower and upper quartiles) (Fig. 3).

Specific ranges of lithium concentrations are distinguished according to the host-rock age of the reservoirs (Fig. 4). Similar median lithium concentrations (3 to $320 \mathrm{mg} \mathrm{l}^{-1}$ ) are found in waters from reservoirs located in formations from the Mesozoic and Palaeozoic-Proterozoic Era, at the exception of reservoirs in the 


\begin{tabular}{|c|c|c|c|c|c|}
\hline \multirow[b]{2}{*}{ Type } & \multirow[b]{2}{*}{ Country } & \multirow[b]{2}{*}{ Deposits } & \multirow{2}{*}{\begin{tabular}{|l|} 
Lithium concentration \\
(Min-Max, ppm) \\
\end{tabular}} & \multirow{2}{*}{\begin{tabular}{|l|} 
Resource \\
(Min-Max, Mtons)
\end{tabular}} & \multirow[b]{2}{*}{ Reference } \\
\hline & & & & & \\
\hline \multirow{51}{*}{ Hard rocks } & Austria & Koralpe & $7500-7800$ & $0.075-0.1$ & $20-21-22$ \\
\hline & Australia & Greenbushes & $12,200-19,000$ & $0.255-0.857$ & $19-21-22$ \\
\hline & Australia & Mt Cattlin Creek & 5000 & $0.0645-0.092$ & $19-21-22$ \\
\hline & Australia & Mt Marion & 6500 & $0.0198-0.069$ & $19-21-22$ \\
\hline & \begin{tabular}{|l|} 
Brazil \\
\end{tabular} & Volta Grande: Mibra & 4600 & $0.1-0.9$ & $17-22-14$ \\
\hline & Canada & Bernic lake & $6400-12,800$ & $0.0186-0.14$ & $19-21$ \\
\hline & Canada & Georgia lake & 4500 & 0.035 & 22 \\
\hline & Canada & James Bay: Cyr & 5800 & 0.129 & 22 \\
\hline & Canada & Lacome: Quebec lithium & $5300-5500$ & 0.574 & $19-22$ \\
\hline & Canada & La Corne & 5200 & $0.1-0.3661$ & $19-21$ \\
\hline & Canada & La Motte & 5000 & $0.0226-1.023$ & $19-21-14$ \\
\hline & Canada & Moblan & $7000-17,000$ & $0.037-0.04$ & $22-14$ \\
\hline & Canada & Mosse & 10,400 & $0.003-0.016$ & $23-22$ \\
\hline & Canada & Separation Rapids: Big Mack & 6200 & 0.072 & 22 \\
\hline & Canada & $\begin{array}{l}\text { Separation Rapids: Big } \\
\text { Whopper }\end{array}$ & 6900 & $0.002-0.072$ & $22-23-14$ \\
\hline & Canada & Wekusko Lake & $6000-7900$ & $0.024-0.072$ & $21-22$ \\
\hline & Canada & Whabouchi & 7100 & 0.21 & 22 \\
\hline & Canada & Yellowknife & $6600-7900$ & $0.1-0.129$ & $19-14$ \\
\hline & China & Daoxian & $2600-5500$ & $0.125-0.182$ & $24-21-22-14$ \\
\hline & China & Yichun & 20,000 & $0.325-0.513$ & $24-21-23$ \\
\hline & China & Jiajika & $5900-6000$ & $0.204-0.48$ & 19-21-17 \\
\hline & China & Lushi & 4600 & 0.093 & 22 \\
\hline & Congo & Kitotolo & 6000 & $0.31-0.8$ & $24-14$ \\
\hline & Congo & Manono & $5800-6000$ & $0.835-3.1$ & $24-21-22$ \\
\hline & Ireland & Blackstairs Mt: Leinster & 6300 & 0.013 & 22 \\
\hline & Finland & Lantta: Oukovesi & 4300 & $0.013-0.68$ & $22-25-14$ \\
\hline & France & Treguebbec & 3300 & 0.13 & 22 \\
\hline & France & Echassières & 3600 & 0.031 & 22 \\
\hline & Mali & Bougouni & 14,000 & $0.004-0.026$ & $19-21-22$ \\
\hline & Namibia & Karibib & $9300-14,000$ & $0.0115-0.15$ & $21-14$ \\
\hline & \begin{tabular}{|l|} 
Portugal \\
\end{tabular} & Brarroso-Alvao & $3700-7700$ & $0.01-0.046$ & $19-23-22$ \\
\hline & Russia & Alakhinskoye & 5100 & $0.046-0.093$ & $23-22$ \\
\hline & Russia & Belorechenskoye & 5200 & $0.046-0.074$ & $23-22$ \\
\hline & Russia & Etykinskoe & $2300-7900$ & 0.046 & $19-23$ \\
\hline & Russia & Goltsovoe & 3700 & $0.139-0.288$ & $17-23-22$ \\
\hline & Russia & Kolmozerskoye & 5300 & $0.288-0.844$ & $17-23-22$ \\
\hline & Russia & Kosterskoye & 2800 & 0.465 & 22 \\
\hline & Russia & Polmostundrovskoye & 5800 & $0.1-0.363$ & $17-23-14$ \\
\hline & Russia & Tastygskoye & 6800 & $0.046-0.279$ & $23-22$ \\
\hline & Russia & Uriskskoye & 5100 & 0.167 & 22 \\
\hline & Russia & Vishnyakovskoe & 4900 & $0.046-0.21$ & $23-14$ \\
\hline & Russia & Zavitinskoye & 3200 & $0.05-0.46$ & $22-23-14$ \\
\hline & Serbia & Jadar valley & 8400 & $0.85-1.048$ & $21-22$ \\
\hline & Spain & Mina Feli & 5000 & 0.005 & 14 \\
\hline & Spain & Doade: Presqueiras & 2500 & 0.025 & 22 \\
\hline & Sweden & Jarkvissle & 4500 & 0.003 & 14 \\
\hline & USA & $\begin{array}{l}\text { McDermitt: Kings River } \\
\text { Valley }\end{array}$ & $2400-5300$ & $0.114-2$ & $20-19-23$ \\
\hline & USA & Bessemer City & 6700 & $0.335-0.42$ & $22-14$ \\
\hline & USA & Kings Mountain belt & $6800-6900$ & $0.2-5.8$ & $19-17-26$ \\
\hline & Zimbabwe & Bikita & $5800-14,000$ & $0.023-0.17$ & $20-22-14$ \\
\hline & Zimbabwe & Kamativi & 2800 & 0.28 & 14 \\
\hline
\end{tabular}




\begin{tabular}{|c|c|c|c|c|c|}
\hline & & & Lithium concentration & Resource & \\
\hline & Country & Reservoir & $\left(\right.$ Min-Max, $\mathrm{mg} \mathrm{l}^{-1}$ ) & (Min-Max, Mtons) & Reference \\
\hline & Canada & $\begin{array}{l}\text { Alberta basin: Fox Creek- } \\
\text { Beaverhill }\end{array}$ & $100-120$ & $0.515-0.589$ & $24-22-21$ \\
\hline & France & $\begin{array}{l}\text { Rhine Graben: Soultz- } \\
\text { Cronenbourg }\end{array}$ & $180-220$ & 0.3 & $27-22$ \\
\hline $\begin{array}{l}\text { Sedimentary formation } \\
\text { waters }\end{array}$ & Russia & $\begin{array}{l}\text { Sayan-Angara-Lena: } \\
\text { Znamenskoye }\end{array}$ & $480-480$ & 0.033 & 22 \\
\hline & USA & Gulf Salt: Smackover & $146-386$ & $0.75-1$ & $27-24-19$ \\
\hline & USA & $\begin{array}{l}\text { Salton Though: Salton Sea- } \\
\text { Brawley }\end{array}$ & $100-400$ & $0.316-1$ & $27-17-14$ \\
\hline & Argentina & Salar de Cauchari & $257-620$ & $0.9-0.926$ & $20-21-14$ \\
\hline & Argentina & Salar des Diablillos & $556-556$ & $0.529-0.9$ & $22-14$ \\
\hline & Argentina & $\begin{array}{l}\text { Salar del Hombre Muerto: } \\
\text { Felix }\end{array}$ & $521-620$ & $0.8-0.9$ & $20-27-25-14$ \\
\hline & Argentina & $\begin{array}{l}\text { Salar del Hombre Muerto: } \\
\text { Sal de Vida }\end{array}$ & $754-754$ & $0.3-1.359$ & $22-14$ \\
\hline & Argentina & Salar de Olaroz & $306-900$ & $0.156-0.325$ & $20-25-17$ \\
\hline & Argentina & Salar de Rincon & $330-400$ & $0.5-2.8$ & $20-25-19-21$ \\
\hline & Bolivia & Salar de Coipasa & $243-350$ & 0.2 & $27-25$ \\
\hline Closed basins brines & Bolivia & Salar de Uyuni & $187-960$ & $5.5-10.2$ & $24-17-28-14$ \\
\hline & Chile & Salar de Atacama & $1400-1570$ & $3-35.7$ & $27-25-29-19$ \\
\hline & Chile & Salar de Maricunja & $920-1240$ & $0.2-0.44$ & $19-21-22-14$ \\
\hline & China & Dangxiongcuo (DXC) & $330-500$ & $0.1-0.2$ & $19-21-14$ \\
\hline & China & $\begin{array}{l}\text { Qinghai: Taijinaier-Da } \\
\text { Qaidam }\end{array}$ & $300-300$ & $1-3.3$ & $19-14$ \\
\hline & China & Zhabuye (Salt lake) & $500-1000$ & $1.3-1.53$ & $27-25-19$ \\
\hline & USA & Clayton Valley: Silver Peak & $200-300$ & $0.04-0.4$ & $29-19-23-14$ \\
\hline & USA & Great Salt Lake & $40-60$ & $0.5-0.526$ & $27-19-21-14$ \\
\hline & USA & Searles Lake & $50-83$ & $0.0182-0.0316$ & $25-19-17-14$ \\
\hline
\end{tabular}

Table 3. Lithium concentrations and lithium resources compiled from published sources of hard-rock deposits, sedimentary formation waters and closed basin brines.

Permo-Triassic series, where they are one to two orders of magnitude lower $\left(0.2\right.$ to $\left.2 \mathrm{mg} \mathrm{l}^{-1}\right)$. They are also lower ( 0.23 to $21 \mathrm{mg} \mathrm{l}^{-1}$ ) and more scattered in reservoirs from the Cenozoic Era than all others.

It is noteworthy that most of the reported lithium concentrations are way above the typical concentration of river waters $\left(10^{-4}-0.1 \mathrm{mg} \mathrm{l}^{-1}\right)^{31}$ and seawater $\left(0.17 \mathrm{mg} \mathrm{l}^{-1}\right)^{32}$, which are the most usual types of waters in the porosity at the time of sediment deposition (i.e. "connate waters"6). The high salinity of surface waters usually results from subaerial evaporation of seawater in sebkhras or continental waters in salars. As lithium is not significantly incorporated in evaporitic minerals, seawater evaporation enriches lithium up to $24.5 \mathrm{mg} \mathrm{l}^{-133}$, thus by a factor of around 100, which cannot explain the highest values reported here. Different processes are needed to explain the high lithium concentrations, such as water-rock interactions ${ }^{34-40}$ along their flow path. Phyllosilicates and volcanic glass are suspected of contributing to the release of lithium, as their lithium content may be significant ${ }^{34-39}$. Additional sources could be clays ${ }^{38,39}$ and carbonates ${ }^{40}$. As the precise mechanisms of lithium enrichment in sedimentary formation waters remain unclear, more experimental work, aided by lithium isotope geochemistry ${ }^{34,40}$, could help to understand lithium release from host rocks. Besides, other processes may decrease lithium concentrations, such as diluting high-salinity sedimentary formation waters by meteoric water, diagenetic water or seawater ${ }^{41}$ and lithium scavenging by clay minerals ${ }^{42,43}$.

\section{Potential lithium resources in sedimentary formations waters}

Estimates of lithium resources were obtained using two scenarios (Tables 2, 3, Fig. 5). Scenario 1 (Sc1) uses lithium concentration equivalent to quartile 1 in the considered reservoir and a porosity value of 0.05 , therefore minimizing the resource estimates. Scenario 2 ( $\mathrm{Sc} 2$ ) uses lithium concentration equivalent to quartile 3 and a porosity value of 0.15 , thus maximizing the resource estimates. In all cases, the resource estimation is conservative as it is based on reasonably minimized reservoir volume, which is the most sensitive parameter in Eq. (1). Resources estimates from Sc1 and Sc2 are shown in Fig. 5a,b respectively, with the lowest and highest available resource estimates for sedimentary formation waters, hard rocks and salars.

Seven reservoirs have been considered for the estimation of lithium resources according to the criteria and conservative approach described in the data compilation and processing section: Oriskany ${ }^{44}$ and Medina ${ }^{45}$ reservoirs in Appalachian Basin, Salton Sea Geothermal System (SSGS) in the Salton Trough ${ }^{46}$, Atlanta field in the North Louisiana Salt ${ }^{47}$, Basal quartz and Leduc formations in Alberta Basin ${ }^{48}$ and Landau oil well in the Rhine Graben $^{49}$. The lithium concentrations of these seven reservoirs range between 11 and $194 \mathrm{mg} \mathrm{l}^{-1}$ and 15 and $277 \mathrm{mg} \mathrm{l}^{-1}\left(\mathrm{Q}_{1}\right.$ and $\mathrm{Q}_{3}$ respectively). 

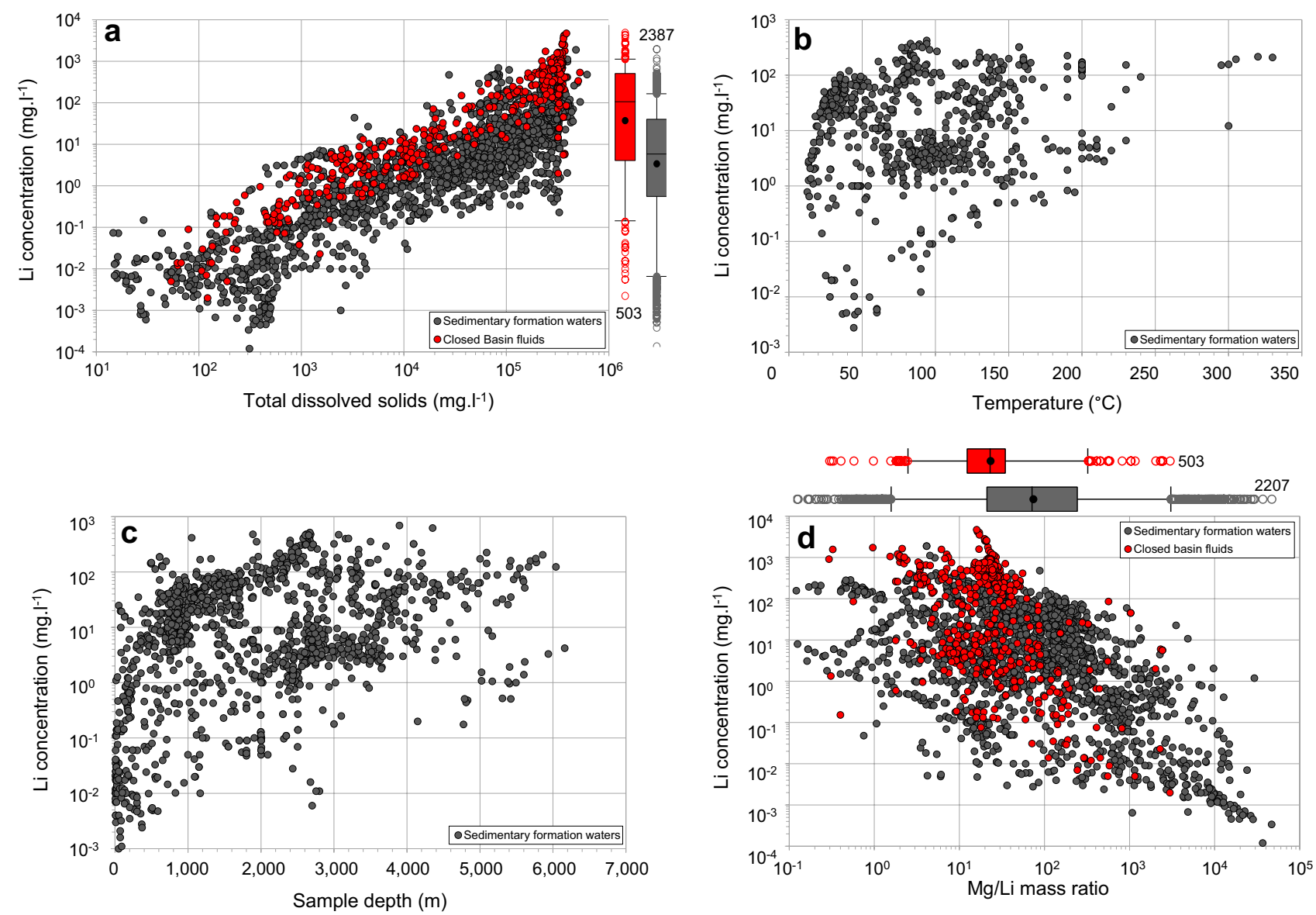

Figure 2. Lithium concentration in formation waters from sedimentary basins and closed basin brines worldwide as a function of various parameters. (a) Lithium concentration vs total dissolved solids. (b) Lithium concentration vs temperature. (c) Lithium concentration vs sample depth. (d) Lithium concentration versus $\mathrm{Mg} /$ Li mass ratio. For box plots, the lower whiskers, bottoms of boxes, central lines, circles, tops of boxes and upper whiskers represent 5 th, 25 th, 50th, average, 75 th and 95 th percentiles, respectively; circles below and above the whiskers represent outliers. The numbers refer to the number of data.

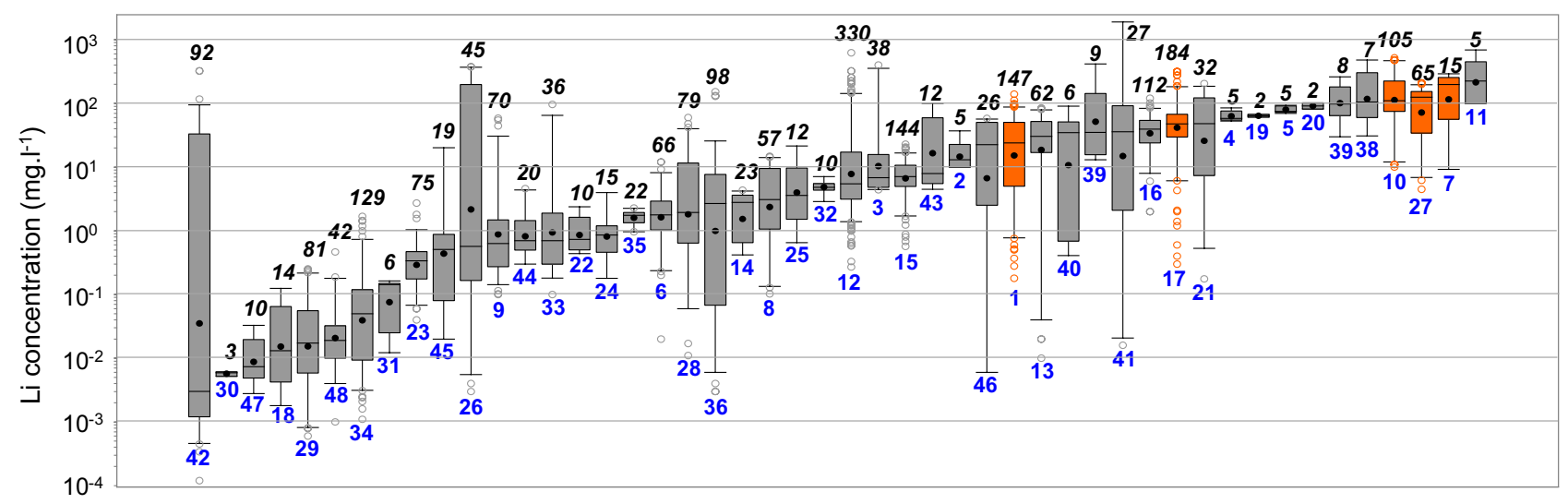

Figure 3. Lithium concentration in formation waters from sedimentary basins worldwide. Each boxplot represents one basin. The box plots are sorted by the increasing median value of Li concentration. The numbers in blue refer to the identification number of the basins (Fig. 1, Table 1). The numbers in black and italics refer to the number of data. Orange box plots indicate the sedimentary basins hosting the reservoirs considered for the resource estimation (see Fig. 5, Table 2). Lower whiskers, bottoms of boxes, central lines, circles, tops of boxes and upper whiskers represent 5th, 25th, 50th, average, 75th and 95th percentiles, respectively; circles below and above the whiskers represent outliers. 


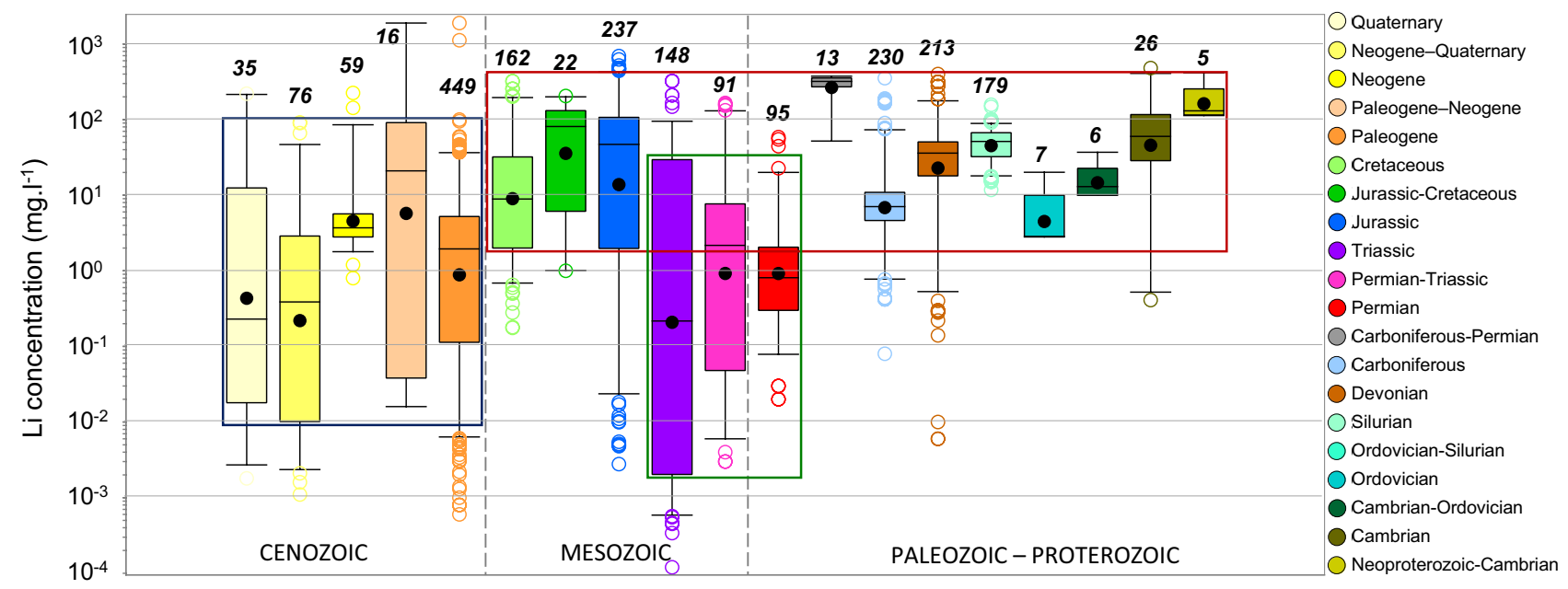

Figure 4. Lithium concentration in formation waters from sedimentary basins worldwide as a function of the age of the host reservoirs. The numbers in black and italics refer to the number of data. Lower whiskers, bottoms of boxes, central lines, circles, tops of boxes and upper whiskers represent 5th, 25th, 50th, average, 75th and 95th percentiles, respectively; circles below and above the whiskers represent outliers. The significances of colored squares are discussed in the lithium geochemistry in sedimentary formation waters section.

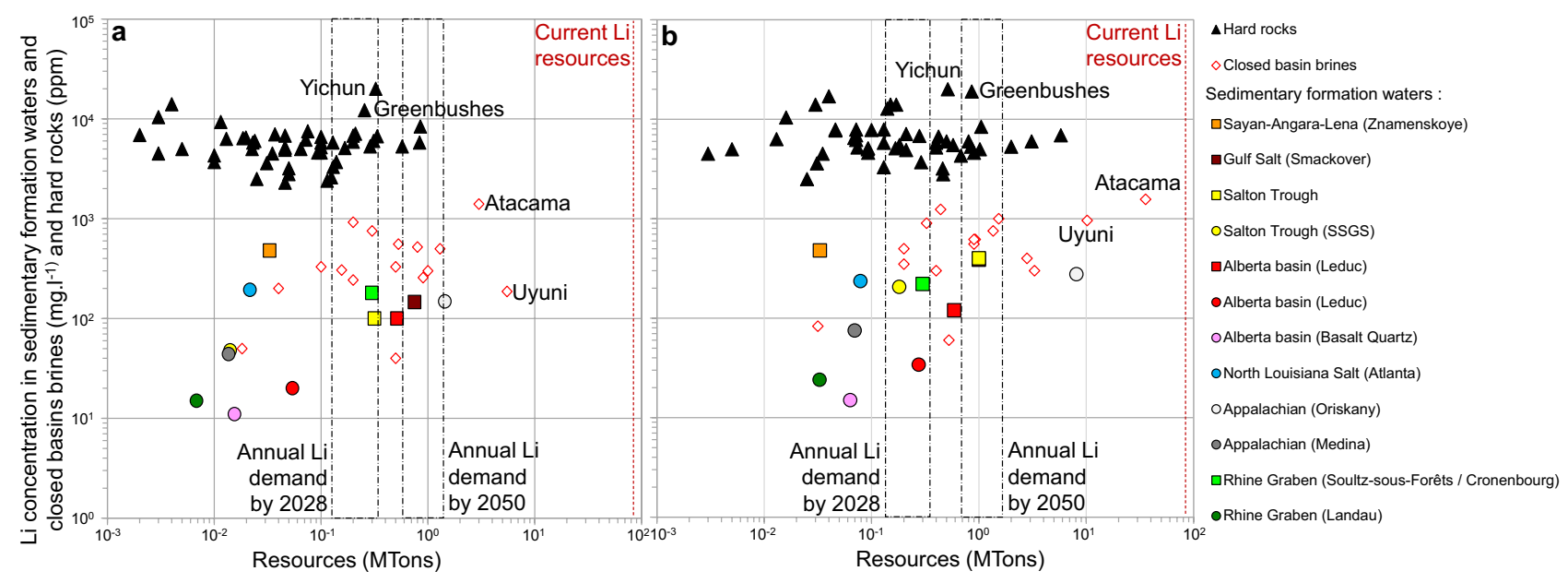

Figure 5. Lithium concentrations versus estimated lithium resources. The data used are reported in Tables 2 and 3 (a) data according to scenario 1 (this study) and lowest available resource estimates (published sources). (b) Data according to scenario 2 (this study) and highest available resource estimates (published sources). Hardrock deposits (triangles); closed basin brines (diamonds); sedimentary formation waters from published sources (squares) $)^{14,17,19-29}$ and this study (circles).

In Sc1, the estimated lithium resources range from 0.01 Mtons (SSGS and Landau well) to 1.44 Mtons (Oriskany reservoir). In Sc2, the estimated lithium resources range from 0.03 Mtons (Landau oil well) to 8.09 Mtons (Oriskany reservoir) (Table 2).

The estimated lithium resources of the seven considered reservoirs increase from scenario 1 to scenario 2 by a factor of 3 to 15 . Although the calculation method is similar, direct comparison of the estimated lithium resources from this study with published lithium resources should be considered with caution as (1) information on input data (surface area, thickness, porosity, lithium concentration, density) is incomplete in the latter and (2) some published lithium resources include two reservoirs such as the Salton Sea and Brawley formations in the Salton Through and Leduc and Beaverhill Lake formations in the Alberta Basin. The estimated lithium resources in Sc1 and Sc2 in SSGS and Leduc formation range from 0.01 to 0.2 Mtons and from 0.05 to 0.28 Mtons. The published lithium resources range from 0.31 to 1 Mtons in Salton Trough and 0.51 to 0.59 Mtons in the Alberta Basin. In the Rhine Graben, estimated lithium resources from this study in the Landau oil well (0.01 to 0.03 Mtons according to Sc1 and Sc2) are significantly lower than published estimates for the Soultz-sousForêts and Cronenburg reservoirs (0.3 Mtons) (Tables 2, 3). Overall, this confirms that the approach developed in this study is conservative.

In both scenarios, the estimated and published lithium resources in the considered reservoirs are in the same range as those of hard-rock mines, and closed basin brines (ca. $10^{-2}$ to $10^{1} \mathrm{Mtons}$ ). The Oriskany reservoir (1.44 to 8.09 Mtons), Leduc formation (0.05 to 0.28 Mtons) and SSGS wells ( 0.01 to 0.2 Mtons) show some comparable 
estimated resources as some major currently exploited lithium deposits in hard rocks such as Greenbushes $(0.26$ to $0.86 \mathrm{Mtons}$ ) and Yichun (0.3 to $0.5 \mathrm{Mtons})$. In Sc2, the estimated lithium resource in the Oriskany reservoir (8.09 Mtons) is comparable to those of the most significant currently-exploited salars, namely Atacama (3 to 35.7 Mtons) and Uyuni (5.5 to 10.2 Mtons).

The forecasted global annual lithium demand ranges between 0.15 and 0.38 Mtons of lithium by $2028^{2}$ and between 0.6 and 1.5 Mtons of lithium by $2050^{50}$ (Fig. 5). The estimated lithium resources from sedimentary formation waters (Oriskany reservoir in Appalachian Basin) are in the same order of magnitude or slightly higher than the forecasted global annual demands for 2028 to 2050 .

\section{Conclusion}

Waters from some sedimentary reservoirs are characterized by high lithium concentrations similar to those from salars. Such waters are brines with salinity ten times higher than seawater. The available resources calculated using conservative hypotheses show that they are comparable to currently-exploited salars and hard-rock mines. According to our conservative estimations, the lithium resources in sedimentary formation waters of some reservoirs may exceed the global annual demand by 2028 and may reach that of 2050 .

Carbon capture, utilisation and storage (CCUS), and low-enthalpy geothermal fields will enhance the production of such waters and favour the potential exploitation of such resources. The production of large quantities of non-drinkable formation waters and associated lithium recovery could finance part of the costs of the CCUS operations. Hydrometallurgical processes such as lithium separation from waters with a high $\mathrm{Mg} / \mathrm{Li}$ ratio will undoubtedly benefit from further improvements.

\section{Data availability}

The published sources used for building the database are available from the corresponding author upon reasonable request.

Received: 28 July 2021; Accepted: 20 September 2021

Published online: 26 October 2021

\section{References}

1. U.S. Geological Survey. Mineral Commodity Summaries (U.S. Geological Survey, 2021).

2. Bibienne, T., Magnan, J.-F., Rupp, A. \& Laroche, N. From mines to mind and mobiles: Society's increasing dependence on lithium. Elements 16, 265-270 (2020).

3. Bradley, D. C. et al. Critical Mineral Resources of the United States-Economic and Environmental Geology and Prospects for Future Supply Ch. K (U.S. Geological Survey, 2017).

4. Romero, H., Mendez, M. \& Smith, P. Mining development and environment injustice in the Atacama desert of Northern Chile. Environ. Justice 5, 70-76 (2012).

5. Hafner, M. \& Tagliapietra, S. The Geopolitics of the Global Energy Transition (Springer, 2020).

6. Kharaka, Y. K. \& Hanor, J. S. Deep fluids in the continents: I. Sedimentary basins. In Treatise on Geochemistry Vol. 5 (ed. Drever, J. L.) 1-48 (Elsevier, 2003).

7. Sverjensky, D. A. Oil field brines as ore forming solutions. Econ. Geol. 79, 23-37 (1984).

8. Alexeev, S. V., Alexeeva, L. P. \& Vakhromeev, A. G. Brines of the Siberian Platform (Russia): Geochemistry and processing prospects. Appl. Geochem. 117, 104588 (2020).

9. Toba, A.-L., Nguyen, R. T., Cole, C., Neupane, G. \& Paranthaman, M. P. U. S. lithium resources from geothermal and extraction feasibility. Resour. Conserv. Recycl. 169, 105514 (2021).

10. McKibben, M. A., Elders, W. A. \& Raju, A. S. K. Lithium and other geothermal mineral and energy resources beneath the Salton Sea. In Crisis at the Salton Sea: Research Gaps and Opportunities 107-122 (Salton Sea Task Force, The EDGE Institute, UC Riverside, 2020).

11. Carpenter, A. B., Trout, M. L. \& Pickett, E. E. Preliminary report on the origin and chemical evolution of lead- and zinc-rich oil field brines in Central Mississippi. Econ. Geol. 69, 1191-1206 (1974).

12. Lund, J. W. \& Toth, A. N. Direct utilization of geothermal energy 2020 worldwide review. Geothermics 90, 101915 (2021).

13. Birkholzer, J. T., Zhou, Q. \& Tsang, C.-F. Large-scale impact of $\mathrm{CO}_{2}$ storage in deep saline aquifers: A sensitivity study on pressure response in stratified systems. Int. J. Greenh. Gas Control 3, 181-194 (2009).

14. Vikstrom, H., Davidsson, S. \& Hook, M. Lithium availability and future production outlooks. Appl. Energy 110, 252-266 (2013).

15. Liu, G., Zhao, Z. \& Ghahreman, A. Novel approaches for lithium extraction from salt-lake brines: A review. Hydrometallurgy 187, 81-100 (2019).

16. Cohen, K. M., Finney, S. C., Gibbard, P. L. \& Fan, J. X. The international chronostratigraphic chart. Episodes 36, 199-204 (2013).

17. Gruber, P. W. \& Medina, P. A. Global Lithium Availability: A Constraint for Electric Vehicles? (University of Michigan, 2010).

18. Ehrenberg, S. N., Nadeau, P. H. \& Steen, O. Petroleum reservoir porosity versus depth: Influence of geological age. Am. Assoc. Pet. Geol. Bull. 93, 1281-1296 (2009).

19. Yaksic, A. \& Tilton, J. E. Using the cumulative availability curve to assess the threat of mineral depletion: The case of lithium. Resour. Policy 34, 185-194 (2009).

20. Evans, R. An abundance of lithium. Environmental Science (2008).

21. Mohr, S., Mudd, G. \& Giurco, D. Lithium Resources and Production: A Critical Global Assessment (Monash University, 2010).

22. Labbe, J. F. \& Daw, G. Panorama 2011 du marché du lithium. BRGM/RP-61340-FR (2012).

23. Grosjean, C., Miranda, P. H., Perrin, M. \& Poggi, P. Assessment of world lithium resources and consequences of their geographic distribution on the expected development of the electric vehicle industry. Renew. Sustain. Energy Rev. 16, 1735-1744 (2012).

24. Clarke, G. M. \& Harben, P. W. Lithium availability wall map (2009)

25. Tahil, W. The Trouble with Lithium 2, Under the Microscope 1-54 (Meridian International Research, 2008).

26. Gruber, P. W .et al. Global lithium availability, a constraint for electric vehicles? Supplementary information. J. Ind. Ecol. 15, 760-775 (2011).

27. Garrett, D. Handbook of Lithium and Natural Calcium Chloride: Their Deposits, Processing. Uses and Properties Ch. Lithium (Academic Press, 2004).

28. Warren, J. K. Evaporites through time: Tectonic, climatic, eustatic controls in marine and nonmarine deposits. Earth Sci. Rev. 98, $217-268(2010)$. 
29. Kunasz, I. Lithium resources. In Industrial Minerals \& Rocks: Commodities, Markets and Uses (eds Kogel, J. E. et al.) 599-614 (Society for Mining, Metallurgy, and Exploration, 2009).

30. Carpenter, A. B. Origin and chemical evolution of brines in sedimentary basins. In SPE Annual Fall Technical Conference and Exhibition (1978).

31. Tomascak, P. B., Magna, T. \& Dohmen, R. Advances in Lithium Isotope Geochemistry: Advances in Isotope Geochemistry (Springer, 2016).

32. Bruland, K. W. \& Lohan, M. C. Controls of trace metals in seawater. In Treatise on Geochemistry Vol. 6 (ed. Elderfield, H.) 23-47 (Elsevier, 2003).

33. Fontes, J. C. \& Matray, J. M. Geochemistry and Origin of Formation Brines from the Paris Basin, France 1. Brines associated with triassic salts. Chem. Geol. 109, 149-175 (1993).

34. Millot, R., Guerrot, C., Innocent, C., Négrel, Ph. \& Sanjuan, B. Chemical, multi-isotopic (Li-B-Sr-U-H-O) and thermal characterization of Triassic formation waters from the Paris Basin. Chem. Geol. 283, 226-241 (2011).

35. Jochens, H. \& Munk, L. A. Experimental weathering of lithium-bearing source rocks Clayton Valley, Nevada, USA. In Society for Geology Applied to Mineral Deposits Antofagasta 238-240 (2011).

36. Seyfried, W. E., Janecky, D. R. \& Mottl, M. L. Alteration of the oceanic crust: Implications for geothermal cycles of lithium and boron. Geochim. Cosmochim. Acta 48, 557-569 (1984).

37. James, R. H., Allen, D. E. \& Seyfried, W. E. Jr. An experimental study of alteration of oceanic crust and terrigenous sediments at moderate temperatures $\left(51\right.$ to $\left.350^{\circ} \mathrm{C}\right)$ : Insights as to chemical processes in near-shore ridge-flank hydrothermal systems. Geochim. Cosmochim. Acta 67, 681-691 (2003).

38. Williams, L. B. \& Hervig, R. L. Lithium and boron isotopes in illite-smectite: The importance of crystal size. Geochim. Cosmochim. Acta 69, 5705-5716 (2005).

39. Mertineit, M. \& Schramm, M. Lithium occurrences in brines from two German salt deposits (Upper Permian) and first results of leaching experiments. Minerals 9,766 (2019).

40. Millot, R., Vigier, N. \& Gaillardet, J. Behaviour of lithium and its isotopes during weathering in the Mackenzie Basin, Canada. Geochim. Cosmochim. Acta 74, 3897-3912 (2010).

41. Hanor, J. S. Origin of saline fluids in sedimentary basins. Geol. Soc. Spec. Publ. 78, 151-174 (1994).

42. Scholz, F. Isotopic evidence $\left({ }^{87} \mathrm{Sr} /{ }^{86} \mathrm{Sr}, \delta^{7} \mathrm{Li}\right)$ for alteration of the oceanic crust at deep-rooted mud volcanoes in the Gulf of Cadiz, NE Atlantic Ocean. Geochim. Cosmochim. Acta 73, 5444-5459 (2009).

43. Castor, S. B. \& Henry, C. D. Lithium-rich claystone in the McDermitt caldera Nevada, USA: Geologic, mineralogical and geochemical characteristics and possible origin. Minerals 10, 68 (2020).

44. Skeen, J. C. Basin Analysis and Aqueous Chemistry of Fluids in the Oriskany Sandstone, Appalachian Basin, USA. Graduate Theses, Dissertations, and Problem Reports (2010).

45. Dresel, P. E. \& Rose, A. W. Chemistry and Origin of Oil and Gas Well Brines in Western Pennsylvania (Geological Survey, 2010).

46. Williams, A. E. \& McKibben, M. A. A brine interface in the Salton Sea Geothermal System, California: Fluid geochemical and isotopic characteristics. Geochim. Cosmochim. Acta 53, 1905-1920 (1989).

47. Moldovanyi, E. P. \& Walter, L. M. Regional trends in water chemistry, Smackover Formation, Southwest Arkansas: Geochemical and physical controls. Am. Assoc. Pet. Geol. Bull. 76, 864-894 (1992).

48. Connolly, C. A., Walter, L. M., Baadsgaard, H. \& Longstaffe, F. J. Origin and evolution of formation waters, Alberta Basin, Western Canada Sedimentary Basin. I. Chemistry. Appl. Geochem. 5, 375-395 (1990).

49. Sanjuan, B. et al. Major geochemical characteristics of geothermal brines from the Upper Rhine Graben granitic basement with constraints on temperature and circulation. Chem. Geol. 428, 27-47 (2016).

50. Xu, C. et al. Future material demand for automotive lithium-based batteries. Commun. Mater. 1, 1-10 (2020).

\section{Acknowledgements}

TotalEnergies financed this work through a CREGU contract. T. Elan, J.-P. Girard and E. Gaucher (TotalEnergies) are warmly thanked for fruitful discussions. The authors are indebted to Alexandre Lebreton, who started building the database for his MSc thesis.

\section{Author contributions}

A.R., M.C., M.-C.B., F.D. and A.B. conceived the project. E.D. compiled the data, prepared the figures and tables and wrote the manuscript. All co-authors discussed the results and edited the manuscript.

\section{Competing interests}

The authors declare no competing interests.

\section{Additional information}

Supplementary Information The online version contains supplementary material available at https://doi.org/ 10.1038/s41598-021-99912-7.

Correspondence and requests for materials should be addressed to E.J.M.D.

Reprints and permissions information is available at www.nature.com/reprints.

Publisher's note Springer Nature remains neutral with regard to jurisdictional claims in published maps and institutional affiliations.

(c) (i) Open Access This article is licensed under a Creative Commons Attribution 4.0 International License, which permits use, sharing, adaptation, distribution and reproduction in any medium or format, as long as you give appropriate credit to the original author(s) and the source, provide a link to the Creative Commons licence, and indicate if changes were made. The images or other third party material in this article are included in the article's Creative Commons licence, unless indicated otherwise in a credit line to the material. If material is not included in the article's Creative Commons licence and your intended use is not permitted by statutory regulation or exceeds the permitted use, you will need to obtain permission directly from the copyright holder. To view a copy of this licence, visit http://creativecommons.org/licenses/by/4.0/.

(C) The Author(s) 2021 